\title{
PAUD Teacher Strategies in Supporting Learning in The Covid-19 Pandemic Period
}

\author{
Fortina Verawati Sianturi \\ Universitas Negeri Medan, Indonesia \\ email: fortinaverawati@gmail.com
}

Received: 13-07-2021

Revised: $15-10-2021$

Accepted: 26-11-2021

Article Info Abstract

Keywords:

Learning Strategy, Covid19, Early childhood.
Kata kunci:

Strategi Pembelajaran, Covid19, Anak Usia Dini.
The existence of COVID-19 which still hit Indonesia until in November 2020 had a negative impact on education in Indonesia, especially early childhood education. This makes learning, which was a face-to-face system, must be changed to distance education. In order for learning to continue optimally, of course, the teacher must be able to apply different learning strategies. In the pandemic era, schools implement online learning strategies, including at the Playgroup level. Online learning for children, of course, presents its challenges for the teachers. This study aims to investigate online learning strategies at the playgroup level. Play is also a means for children to channel their great energy and discover new things that were previously unknown in a fun way. And this is certainly different from learning that is understood by adults with all the rules and demands at the end. Playing (while learning) in early childhood has a purpose that adults may not realize, where when a child plays, in fact he is developing the potential that exists within him to become a solid initial capital for himself in the future when facing problems in life. This paper is expected to provide references and education to parents and early childhood teachers in particular to be able to understand the world of early childhood, one of which is by understanding the nature of play and the meaning of play for early childhood. This is obtained by exploring various sources from several literatures from the results of research and thought where the results can be used for early childhood parents and teachers to be more precise in assisting and designing learning for early childhood so that the pearl of early childhood learning, namely playing while learning can be achieved.

\footnotetext{
Abstrak

Keberadaan COVID-19 yang masih melanda Indonesia bingga November 2020 membawa dampake negatif bagi pendidikan di Indonesia, khususnya pendidikan anak usia dini. Hal ini membuat pembelajaran yang tadinya bersifat tatap muka harus diubah menjadi pendidikan jarak jauh. Agar pembelajaran dapat berlangsung secara optimal, tentunya guru barus mampu menerapkan strategi pembelajaran yang berbeda. Di era pandemi, sekolah menerapkan strategi pembelajaran daring, termasuk di tingkat Playgroup. Pembelajaran daring untuk anak tentu saja menghadirkan tantangan tersendiri bagi para guru. Artikel ini bertujuan untuk mengetahui strategi pembelajaran daring di tingkat playgroup. Bermain juga merupakan sarana bagi anak untuk menyalurkan energinya yang besar dan menemukan hal-hal baru yang sebelumnya tidak diketabui dengan cara yang menyenangkan. Dan hal ini tentunya berbeda dengan pembelajaran yang dipabami oleh orang dewasa dengan segala aturan dan tuntutan pada akhirnya. Bermain (sambil belajar) pada anak usia dini memiliki tujuan yang mungkin tidak disadari oleh orang dewasa, di mana ketika seorang anak bermain, sebenarnya ia sedang mengembangkan potensi yang ada dalam dirinya untuk menjadi modal awal yang kokoh bagi dirinya di masa depan ketika menghadapi masalah dalam kehidupan. Tulisan ini diharapkan dapat memberikan referensi dan edukasi kepada orang tua dan guru PAUD kbususnya untuk dapat memahami dunia anak usia dini, salah satunya dengan memahami hakikat bermain dan makna bermain bagi anak usia dini. Hal
} 
ini diperoleh dengan menggali berbagai sumber dari beberapa literatur dari hasil penelitian dan pemikiran yang mana hasilnya dapat digunakan untuk orang tua dan guru PAUD agar lebih tepat dalam mendampingi dan merancang pembelajaran untuk PAUD sehingga menjadi mutiara pembelajaran PAUD, yaitu bermain sambil belajar dapat tercapai.

\section{INTRODUCTION}

Education is an investment in the future to prepare quality human resources (HR). Experts generally have the view that education is a process of developing individual potential, cultural inheritance and the interaction between individual potential and the culture of the environment. The essential purpose of education is to develop the potential and abilities of students to maintain and improve human dignity, namely humans who have intelligence (intelligence, spiritual, emotional) to live their lives responsibly, both personally, socially and professionally (Azizah \& Fajeriah, 2021). The impact of the Coronavirus Disease (Covid-19) in Indonesia occurred in the education sector from preschool to university level. All levels of formal education underwent several policy changes as well as the COVID-19 pandemic still enveloped the world until November 2020 and had a significant impact on education patterns, especially in Indonesia (Safriyani et al., 2021).

Indonesia is one of the countries affected by COVID-19 and until September 2021 there has been no bright spot for the end of this outbreak, Indonesia still recorded the highest death toll in Southeast Asia. Teachers anticipate the number of infections that are increasing day by day, the government has issued policies such as self-isolation, social and physical distancing to large-scale social restrictions in various cities (Saleh et al., 2021). This condition requires every citizen to stay at home, work and study at home. As a step in tackling the spread of COVID-19, which has increased until this November, the application of health protocols is still being applied vigorously in every agency and every region to remote areas, especially in public places. In the teaching of odd semester learning in 2020, the government still provides a policy to require online learning at all levels of education. Various levels of education have felt a very bad impact with the spread of COVID, especially PAUD (Munjiat, 2020). The COVID outbreak has made many public activities shift with the main center of activity being at home. This situation is a new reality that is also experienced by the world of education, especially at the PAUD level (Syafi'uddin, 2014).

Learning with the characteristics of playing in early childhood education is a fun, entertaining, and creative learning process. The learning process is fun, entertaining, and creative can provide a sense of security and comfort in early childhood. In this pandemic period, so that learning is more interesting and can achieve the target, careful plans and stages as teachers are needed to optimize the interaction between children and teachers, but not only teachers as educators who are careful to deal with this, but also parents. This learning optimization is of course determined from the cooperation of several core parties, namely the kindergarten principal, teachers, and also parents Danim in (Iffah \& Fauziyah, 2021).

The factors that need to be owned by schools if they want to improve the quality of learning are the leadership of principals, teachers, students, curriculum, and collaborative networks. Teachers are required to be as creative as possible in packaging learning so that the message to be conveyed through learning activities can be conveyed properly to children. (Botutihe et al., 2020) educators have a role as planners and parents are the parties who become 
the liaison for learning activities for children. So that the designs that have been made can be conveyed correctly to children, strategies, and creativity from the teacher are needed in packaging the learning (Ilmi et al., 2021).

Applying various methods is also a strategy for teachers, including learning while playing, where: Meaning and benefits of play for children an important function of play is that it is directly related to problem-solving abilities, providing individuals with specific skills to solve the various problems that arise (Kurniasih et al., 2021). Play is a child's world and childhood to explore all that is in children. Games in children are all activities carried out by children in the form of movements, thoughts, and words. Play in the form of movements such as: running, jumping, climbing, and others. Playing that uses the mind such as: playing puzzles, arranging blocks, remembering songs, remembering other people's dialogues that are listened to. Playing with words is a way for children to express their feelings in words and imitate the words of others. The experts conclude that children are very creative and dynamic creatures. Children's needs are only to play, whether done alone or done together (group)(Masitah \& Sitepu, 2021).

The meaning of playing for children from the results of research, observations, and experiences of experts that by playing a child will be able to develop several things in himself, including: 1) Children have the opportunity to express and explore what is in them. 2) Interests, talents, abilities, and weaknesses will appear and be seen in a child. 3) Children have the opportunity to develop five aspects of early childhood development, namely physical, motor, language, cognitive, and religious morals. 4) The five senses will develop well because when playing children use all their five senses. 5) Be motivated to know something.

Character of children's way to learn Children's way of learning is different from that of adults, so learning must be done with different strategies. Learning for a child has its characteristics that are different from adults, including playing while learning, natural learning, and building their knowledge. Groos1 has hypothesized that one of the important functions of games is directly related to problem-solving abilities, providing individuals with specific skills to solve various problems posed in other life circumstances. Play is considered as an orientation that gives individuals the ability to apply a large part of themselves where the experience of playing with objects and procedures is to real-life problems that do not arise in the original game situation (Syafi'uddin, 2014). This is following the views of constructivist experts regarding learning in children which gives rise to the ability to build knowledge by playing through exploration carried out on the objects encountered and the interactions they do.

There are two general thoughts about how a game can contribute to the development of divergent thinking skills. The first is the assumption that play is a contribution to the development of thinking skills based on its experimental and flexible nature. The benefit of this experimental nature of play is that it provides a broad repertoire of skills and responses to children, and with a flexible approach used to effectively complete different tasks or thinking problems. A second way of looking at the relationship between play and different thinking skills is to focus on the symbolic, pretentious nature that characterizes many young children's play. This has been stated by several experts, that there is a theory, namely that playing serves to Mulyasa in (Febrialismanto, 2017).

Facilitate the child's transition from concrete to abstract thought processes (Syafi'uddin, 2014). It has been argued that symbolic representations are so often produced in the form of games which are part of the process through which a child develops the ability to think abstractly. An early childhood, in general, has a view of everything as a whole thing that is 
concrete and directly felt and experienced by him. Thus, the way children learn has several special characteristics that can be identified as follows. 1) Learning through reflex movements and body activities. 2) Learn to act out his feelings and conscience. 3) Learn while playing. 4) Learning through communication, interaction, and socialization. 5) Learn from the environment. 6) Learn to fulfill desires and needs.

The selection of PAUD learning strategies needs to pay attention to the nature and development of early childhood, as researched by experts, including by Bredecam and Copple, Brener, and Kellough: 1). Children develop according to their respective abilities. Each child has its own characteristics 2). Children express their behavior relatively spontaneously. 3). Children are individuals who are free to move and are free to be creative. 4). Children are egocentric. 5). Children have a great curiosity about new things. 6). Children have a strong adventurous spirit. 7). Children have a lot of imaginations. 8). Children are still easily frustrated. 9). Children still lack calculations in doing things. 10). Children have a short attention span. 11). Children have enormous potential in terms of learning. 12). Children show more interest in friends. In determining learning strategies for preschool children, teachers who understand the ins and outs of early childhood education are needed, among early childhood science is understanding the character of early childhood, how to learn, how to develop social-emotional, language, cognitive so that an early childhood teacher can reduce errors in designing an early childhood education (Akbar, 2020).

Benefits of learning while playing. 1) Play triggers creativity Safe and fun games encourage children to play and find ideas and use their imagination. The results of the study support the notion that play and creativity are interrelated because both play and creativity rely on children's ability to use symbols.10 Creativity is seen as an aspect of problem-solving from the basic roots of play. When children use their imagination, whether with tools or not, their creativity is more prominent. 2) Playing is useful for educating the brain. Playing is a very crucial medium in children's thinking processes. The cognitive development of children cannot be separated from a process called to play. A sense of pleasure in playing helps the intellectual development or intelligence of children's thinking which will later get various experiences so that they can enrich their way of thinking (Chen \& Liu, 2021; Chuang et al., 2021; Satria \& Herumurti, 2021). 3) Playing is useful in overcoming conflict. In early childhood or kindergarten, the behavior that often appears is counter-social behavior, for example, selfish, aggressive, hyperactive, competitive, angry, imitating, fighting, and wanting to win on their own. But it must be understood that such behavior is unavoidable, counter-social behavior is needed to be able to direct children to prosocial attitudes. Kindergarten provides a great opportunity for children to be directed into positive things through playing in conflicts that occur. Playing plays, free plays, and stories through various methods are the intended activities. 4) Play is useful for practicing empathy. Empathy is the feeling of someone who feels what other people feel. By having empathy, children will be good at placing themselves in other people's circumstances, and tolerance will appear. 


\section{RESEARCH METHODS}

This study uses a descriptive type of research. The research aims to observe and describe aspects of a situation as it occurs naturally (Creswell, 2012). Data collection techniques using a questionnaire. The questionnaire instrument used is a development questionnaire from an existing questionnaire. This study aims to describe the strategies used by teachers in Kindergarten in supporting learning during the pandemic. The research was conducted in Early Childhood Education. The research instrument used was an open questionnaire, a questionnaire created using a google form which was distributed online via WhatsApp. The participants involved in this study were 10 teachers who were focused on the North Sumatra region. This research questionnaire was developed from Visual Systems and Autistic Children Peeters in (Tissot \& Evans, 2003) and e-learning readiness of Hong Kong teachers (Swatman, 2006). Data processing was carried out by concluding using docs.google.com which directly produced answers (Nasution \& Sutapa, 2021).

\section{RESULTS AND DISCUSSION}

Efforts to create a superior and quality generation, education must be carried out from an early age and lasts a lifetime (long-life education). Early childhood is a time when children grow and develop very rapidly. So rapidly, the age of 0-6 years is called the golden age (Golden Age) by experts. In this golden age, children have a lot of potentials that can be developed optimally, and to develop children's potential effectively, children need to get an education. A good education will make children grow and develop well. This means that early childhood education (PAUD) is very essential for the further development of children.

Learning at PAUD institutions must also prioritize standards in the implementation of early childhood education according to the standards set by the government in Government Regulation Number 19 of 2005 concerning national education standards which are formulated into 4 groups, namely standards for developmental achievement levels, standards for educators and education personnel, content standards, process and assessment standards and infrastructure, management, and financing standards (Syafi'uddin, 2014).

Implementation is the process of applying ideas, concepts, policies, or innovations in a practical action to have an impact in the form of changes, knowledge, skills as well as values and attitudes towards the actors in the objects that are subjected to this implementation process. Implementation is also defined as the implementation or application that is implemented and applied is the curriculum or designed to be carried out fully. Implementation is usually the implementation of a plan that has been prepared carefully and in detail. Implementation is usually done after the planning is considered perfect (Mulyasa, 2013)

From the understanding of these experts, it can be drawn some similarities, namely the existence of a process of collecting data or information to be able to measure and assess the abilities or strengths and difficulties, and weaknesses that will be selected in children so that they know what children need in their development. The assessment is not carried out at the end of the program but is carried out face-to-face and continuously so that the progress of students can be known, namely by observing children's behavior when playing drawing or from the results of children's activities and other children's works. The term strategy comes from the Greek strategy $($ Stratos $=$ military and ag $=$ lead $)$, which means the art or science of becoming a general. Strategy 
can be interpreted as a plan for the distribution and use of military and material forces in certain areas to achieve certain goals of action (Setiawan et al., 2021).

Strategy is the science of planning and determining the direction of large-scale business operations, mobilizing all the company's resources that can benefit the business, John A. Bryne in (Jarvis, 2013) defines strategy as a fundamental pattern of goals and plans, deployment of resources, and interaction of the organization with the market, competitors, and environmental factors.

Table. 1

PAUD Teacher Strategies in Supporting Learning in the Covid-19 Pandemic Period

\begin{tabular}{ll}
\hline Teacher Strategy & Strategy \\
\hline Applying forms of learning that & Teachers provide learning activities in various forms \\
are following the needs of early & such as learning through videos, giving assignments, \\
childhood & home visits, \\
& use of worksheets, and face-to-face groups \\
& 1-7 children. The teacher also sees current activities \\
& while at school like teaching sticking, \\
& cutting, drawing, coloring, thickening, \\
& and writing the beginning, the concept of numbers. \\
& Then \\
& make it as simple as possible so you can \\
& children understand. Make learning according to the \\
& theme \\
& and what's happening right now \\
The teacher and parents give assignments to \\
children to learn to bathe themselves, wear clothes \\
alone, eat, tidy up equipment \\
play alone, tidy up study equipment \\
themselves, parents record children's activities, and \\
provide a video to submit to the teacher. \\
The teacher uses audiovisual, laptop, LCD, \\
take advantage of the zoom meeting application, \\
WhatsApp, \\
or manual
\end{tabular}

The table above describes the process of activities and strategies used by teachers in the process of learning is very diverse. During this pandemic, teachers have the freedom to use various strategies in learning, so that it allows learning to be interesting and children do not lose 
the opportunity to learn even though it is at home. Online learning can also be accessed by parents who have been provided by the Ministry of Education and Culture such as TVRI, YouTube Kids, or other applications. Following strategy guidelines or making activity plans through their videos also greatly sharpens the creativity of teachers in providing learning to early childhood. The form of learning can also be packaged by the teacher such as doing online learning by utilizing applications such as zoom meeting, WhatsApp, and Microsoft team, the teacher gives tasks that children must do at home, provides modules as a guide for parents in guiding children to visit children's homes., and the teacher also does face-to-face the group while still adhering to health protocols. Teachers can also see firsthand the development of children while studying at home. the results of the teacher making digital handbooks, delivering notifications through websites and online applications, making learning videos such as singing and reading stories. In addition to learning through the application of visiting children's homes, it is also one of the alternatives carried out by teachers so that children still feel close to the teacher and are not bored with online learning. The concept of early childhood learning is concrete learning. When explaining learning to children, it is necessary to have media that can help children understand the material presented. Therefore, the media is needed in learning. coupled with the current conditions, the learning media used are more application-based to support learning well.

Having a cooperative relationship with parents is also very important. Currently, it is parents who play a major role in assisting children at home. cooperation between schools and parents will have a good impact on children's education. Based on research (Hapsari et al., 2020) collaboration with parents is communication that aims to make the education given to children can be carried out in any situation. the limitations of teachers when doing learning through applications can be improved with the help of parents to convey learning messages to children. Therefore, communication is very important for teachers to do and parents.

\section{CONCLUSION}

This study shows that the learning strategies in Kindergarten Parks in optimizing the learning process of early childhood education include teacher learning strategies during the pandemic that have been successfully running optimally with achievements related to the strategies used in learning and learning activities that suit the needs of students. Among them is by applying learning strategies while playing by showing several video shows, animations, and creating various games that can motivate children. Good communication is needed, especially to parents of children so that the learning process can run optimally as expected.

\section{REFERENCES}

Akbar, E. (2020). Metode Belajar Anak Usia Dini. Prenada Media.

Azizah, A., \& Fajeriah, S. (2021). The Effect of Offline Learning Model Assisted in Practicum Discovery Learning on Learning Outcomes. Nazhruna: Jurnal Pendidikan Islam, 4(3), 663671. https://doi.org/10.31538/nzh.v4i3.1667

Botutihe, S. N., Smith, M. B., Kasan, I. A., \& Hilala, R. (2020). Strategi Pembelajaran Physical Distancing Guru PAUD dalam Menghadapi Pandemi Covid19. Jurnal Obsesi: Jurnal Pendidikan Anak Usia Dini, 5(2), 1536-1543. 
Chen, S., \& Liu, Y.-T. (2021). Learning by designing or learning by playing? A comparative study of the effects of game-based learning on learning motivation and on short-term and long-term conversational gains. Interactive Learning Environments, $0(0), 1-15$. https://doi.org/10.1080/10494820.2021.1961159

Chuang, T.-Y., Yeh, M. K.-C., \& Lin, Y.-L. (2021). The Impact of Game Playing on Students' Reasoning Ability, Varying According to Their Cognitive Style. Educational Technology \& Society, 24(3), 29-43.

Creswell, J. W. (2012). Qualitative Inquiry and Research Design: Choosing Among Five Approaches. SAGE Publications.

Febrialismanto, F. (2017). Analisis Kompetensi Profesional Guru Pg Paud Kabupaten Kampar Provinsi Riau. Jurnal Pendidikan Anak, 6(2), 121-136. https://doi.org/10.21831/jpa.v6i2.17700

Hapsari, S. M., Sugito, S., \& Fauziah, P. Y. (2020). Parent's Involvement in Early Childhood Education during the Covid-19 Pandemic Period. Jurnal Pendidikan Progresif, 10(2), 298311.

Iffah, F., \& Fauziyah, Y. (2021). Marketing Management of Boarding School in Increasing Community Interest. Nidhomul Haq: Jurnal Manajemen Pendidikan Islam, 6(2), 309-322. https://doi.org/10.31538/ndh.v6i2.1574

Ilmi, M. U., Setiawan, F., Hikmah, M. N., Kharisma, A., Feryawan, D., \& Hanafie, A. A. (2021). The Basic Concepts of Evaluation and Its Implementation in IRE Lessons in The Pandemic Era. Tafkir: Interdisciplinary Journal of Islamic Education, 2(2), 175-190. https://doi.org/10.31538/tijie.v2i2.50

Jarvis, P. (2013). Learning in Later Life: An Introduction for Educators and Carers. Routledge. https://doi.org/10.4324/9781315042435

Kurniasih, E., Haryati, Y., \& Rachmiazasi Masduki, L. (2021). Evaluation of using VAR (Virtual Augmented Reality) based educational games in Islamic kindergartens in Semarang City (SSRN Scholarly Paper ID 3865585). Social Science Research Network. https://doi.org/10.2139/ssm.3865585

Masitah, W., \& Sitepu, J. M. (2021). Development of Parenting Models in Improving Children's Moral Development. Nazhruna: Jurnal Pendidikan Islam, 4(3), 769-776. https://doi.org/10.31538/nzh.v4i3.1692

Mulyasa, E. (2013). Pengembangan dan implementasi kurikulum 2013. PT Remaja Rosdakarya.

Munjiat, S. M. (2020). Implementation of Islamic Religious Education Learning in Higher Education on The Pandemic Period. Nazhruna: Jurnal Pendidikan Islam, 3(2), 285-295. https://doi.org/10.31538/nzh.v3i2.757

Safriyani, R., Wakhidah, E. W., \& Supriyanto, C. (2021). Strategi Pembelajaran Daring Anak Usia Dini pada Masa Pandemi Covid. Musamus: Journal of Primary Education, 3(2). https://doi.org/10.35724/musjpe.v3i2.3227

Saleh, M. N. I., Sari, R., \& Alim, P. (2021). University Students' Perception on The Implementation of Online Learning During The Covid-19. Ną̧runa: Jurnal Pendidikan Islam, 4(1), 1-17. https://doi.org/10.31538/nzh.v4i1.1022

Satria, V. H., \& Herumurti, D. (2021). Role-Playing Game as Learning Media To Support Online Learning. Journal of Education Technology, 5(4), 579-587. https://doi.org/10.23887/jet.v5i4.39718 
Setiawan, J., Sudrajat, A., Aman, \& Kumalasari, D. (2021). Development of Higher Order Thinking Skill Assessment Instruments in Learning Indonesian History. International Journal of Evaluation and Research in Education, 10(2), 545-552.

Syafi'uddin, I. (2014). Strategi Penerapan Pendidikan Agama Islam di Lingkungan Keluarga Pedagang Muslim Kelurahan Tompokersan Lumajang. UIN Malang. 